\title{
Response to atracurium and mivacurium in a patient with Charcot- Marie-Tooth disease
}

Mohamed Naguib MB BCH MSC FFARCSI MD, Abdulhamid H. Samarkandi MB BS JB KSUF FFARCSI

Purpose: We studied the neuromuscular effects of both atracurium and mivacurium in a patient with CharcotMarie-Tooth disease (CMTD) during nitrous oxide-oxygen-alfentanil-propofol anaesthesia. Neuromuscular blockade was monitored electromyographically. Train-of-four stimulation ( $2 \mathrm{~Hz} @ 20$ sec intervals) was delivered to the ulnar nerve throughout the period of observation.

Clinical features: A 17-yr-old man with the diagnosis of CMTD was presented twice for two different orthopaedic surgical procedures. The CMTD had been diagnosed since childhood. Neurological examination revealed distal wasting of the upper and lower limbs, generalised absence of reflexes and decreased sensation in a stocking distribution. In both anaesthetics, induction was carried out with alfentanil and propofol, and anaesthesia was maintained with nitrous oxide in oxygen, alfentanil and propofol infusion. The patient demonstrated a normal response to both atracurium and mivacurium. Onset time and the maximum block attained after atracurium and mivacurium were 240 and $210 \mathrm{sec}$, and $97 \%$ and $99 \%$ inhibition of TI (the first twitch of TOF stimulation), respectively. Recovery of $\mathrm{TI}$ to $10 \%$ of the control value occurred 30 and $11.5 \mathrm{~min}$ after the administration of atracurium and mivacurium, respectively. The patient made uneventful recoveries after both anaesthetics.

Conclusion: There was no evidence of prolonged response to atracurium and mivacurium in our patient with CMTD.

Objectif : Étudier les effets neuromusculaires de l'atracurium et du mivacurium chez un patient affligé du syndrome de Charcot-Marie-Tooth (SCMT) pendant l'anesthésie au protoxyde d'azote-oxygène-alfentanilpropofol. Un moniteur électronique servait à évaluer la curarisation. Le train-de-quatre (TOF, $2 \mathrm{~Hz}$ aux $20 \mathrm{~s}$ ) stimulait le nerf cubital pendant la période d'observation.

Éléments cliniques : Un homme de 17 connu depuis sa naissance comme souffant de SCMT a dû être opéré à deux reprises pour des intervention orthopédiques différentes. L'examen neurologique a révélé une atrophie musculaire aux membres supérieurs et inférieurs, une absence généralisée des réflexes et une sensibilité distale diminuée selon une distribution en chaussette. Au cours des deux anesthésies, on a utilisé de l'alfentanil et du propofol pour l'induction et, pour le maintien, du protoxyde d'azote en oxygène, et de l'alfentanil et du propofol en perfusion. Le patient a répondu normalement autant à l'atracurium qu'au mivacurium. Le début d'action et la curarisation maximale de l'atracurium et du mivacurium étaient respectivement de $240 \mathrm{~s}$ et de $210 \mathrm{~s}$ et l'inhibition de $T_{1}$ de $97 \%$ et $99 \%$ (la première stimulation du TOF). La récupération de $T_{1}$ à $10 \%$ du contrôle survenait 30 et $11,5 \mathrm{~min}$ après l'administration de l'atracurium et du mivacurium. Le patient a récupéré sans complication après les deux anesthésies.

Conclusion : Le SCMT ne prolonge pas l'action de l'atracurium et du mivacurium.

From the Department of Anaesthesia, King Saud University, Faculty of Medicine at King Khalid University Hospital, Riyadh, Saudi Arabia. Address correspondence to: Dr. Mohamed Naguib, Department of Anaesthesia, Faculty of Medicine at King Khalid University Hospital,

P.O. Box 7805, Riyadh 11472, Saudi Arabia. Phone: 966-1-4671578; Fax: 966-1-4679493; E-mail: F35A002@KSU.EDU.SA. Accepted for publication October 2, 1997. 


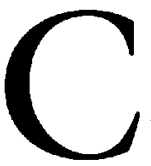

HARCOT-MARIE-TOOTH disease (CMTD) consists of a heterogeneous group of neurological disorders characterised by peripheral motor and sensory neuropathy. Seven types of this disorder were proposed in $1975 .{ }^{1}$ Charcot-Marie-Tooth disease type $1 \mathrm{~A}$ or hereditary motor and sensory neuropathy type Ia is an autosomal dominant demyelinating polyneuropathy. Peroneal nerve atrophy leading to weakness in the anterior and lateral compartments is the most common clinical pattern in CMTD, but considerable variability exists in the pattern of atrophy. Abnormalities of feet and toes, including pes cavus, are usually present. Intrinsic atrophy of the calf musculature is a common finding in CMTD. The sensory disturbance is milder than the motor disturbance. Autonomic disturbances such as orthostatic hypotension and hypohidrosis are occasionally reported. ${ }^{2}$ Pregnancy may be associated with exacerbations of CMTD. ${ }^{3}$

Patients with CMTD have been reported to be sensitive to the effects of thiopentone. ${ }^{2}$ Respiratory insufficiency has also been described in patients with CMTD on the basis of respiratory muscle dysfunction. ${ }^{4-6}$ Loss of motor units and the resultant muscle weakness in CMTD might result in sensitivity to nondepolarising neuromuscular blocking drugs. There are, however, conflicting reports on the response of patients with CMTD to the nondepolarising neuromuscular blocking drugs. ${ }^{2,7-10}$ Kotani et al. ${ }^{2}$ reported that facial movement upon electrical stimulation was absent $135 \mathrm{~min}$ after administration of $3.5 \mathrm{mg}$ vecuronium to a $50-\mathrm{kg}$ patient with CMTD. In contrast, Baraka ${ }^{10}$ noted a normal response, or even a moderate resistance, to vecuronium in a patient with CMTD.

We report the anaesthetic management of a patient with CMTD, and the response to both atracurium and mivacurium.

\section{Case report}

A 17-yr-old man weighing $64 \mathrm{~kg}$, and $176 \mathrm{~cm}$ in height, with the diagnosis of CMTD presented twice for two different orthopaedic surgical procedures. In July 1996, he was scheduled for triple arthrodesis of his right subtalar joint and in January 1997 for arthroscopy of his right knee. The CMTD had been diagnosed since childhood. There was no family history of the disease. Four years earlier, the patient sustained trauma that resulted in fracture of the tarsal bones of his right foot. The rest of his history was unremarkable. Neurological examination revealed normal high mental function, intact cranial nerves, distal wasting of upper and lower limbs, generalised absence of reflexes and decreased sensation in a stocking distribution. The vital signs and results of laboratory tests were normal. The reported plasma cholinesterase activity was $10.8 \mathrm{U} \cdot \mathrm{ml}^{-1}$ (reference range $\left.3.5-13 \mathrm{U} \cdot \mathrm{ml}^{-1}\right)$. The dibucaine number was 87 (normal range 80-88) and the fluoride number was 48 (normal range 45-55). Informed consent was taken to study the patient's response to both atracurium and mivacurium.

\section{Anesthesia}

The anaesthetic technique was similar in both anaesthetics except for the nondepolarising neuromuscular blocking drug used. Atracurium was used in the first and mivacurium in the second.

No premedication was given. An intravenous catheter for fluid and drug administration was inserted. The ECG, $\mathrm{SpO}_{2}$ and $\mathrm{BP}$ were monitored. Temperature was monitored by a nasopharyngeal thermistor and maintained between 35.5 and $37.5^{\circ} \mathrm{C}$.

Anaesthesia was induced with $0.5 \mathrm{mg}$ alfentanil and incremental doses of propofol, and was maintained with nitrous oxide $70 \%$ in oxygen and propofol infusion, 75-100 $\mu \mathrm{g} \cdot \mathrm{kg}^{-1} \cdot \mathrm{min}^{-1}$, and alfentanil. Topical anaesthesia of the larynx and trachea was achieved by spraying 4 $\mathrm{ml}$ lidocaine $4 \%$. The concentrations of nitrous oxide, oxygen, and carbon dioxide were measured continuously by a multiple-gas analyser (Narkomed 4). Ventilation was adjusted to maintain normocapnia (end-tidal partial pressure of carbon dioxide $\left[\mathrm{P}_{\mathrm{ET}} \mathrm{CO}_{2}\right]$ $35-40 \mathrm{~mm} \mathrm{Hg}$ ).

Following induction of anaesthesia, the indirectly evoked integrated compound action potential of the adductor pollicis muscle to supramaximal stimulation of the ulnar nerve at the wrist was measured and recorded using a Datex ${ }^{\mathrm{TM}}$ monitor. Supramaximal nerve stimulation was achieved using the nerve stimulator incorporated into the Datex unit (pulse width $100 \mathrm{msec}$, constant current, $0-70 \mathrm{~mA}$ range). Trainof-four (TOF) stimulation repeated every $20 \mathrm{sec}$ with a frequency of $2 \mathrm{~Hz}$ and an intensity of $70 \mathrm{~mA}$ was used to monitor neuromuscular function.

In the first anaesthetic, after a five-minute period of baseline stabilisation, $0.5 \mathrm{mg} \cdot \mathrm{kg}^{-1}$ atracurium was administered. The first measurable effect (lag time) and the maximum neuromuscular block (onset time) developed in 60 and $240 \mathrm{sec}$, respectively. The maximum block attained was $97 \%$ inhibition of $\mathrm{Tl}$ (the first twitch of TOF stimulation). Thereafter, tracheal intubation was carried out. The first twitch (T1) recovered to $10 \%$ of the control value $30 \mathrm{~min}$ after the administration of atracurium. A supplementary dose of $0.1 \mathrm{mg} \cdot \mathrm{kg}^{-1}$ atracurium was required every $11 \mathrm{~min}$ to maintain $\mathrm{Tl}$ at $10 \%$ of control value and a total of five supplementary doses were administered throughout surgery. After the last supplementary dose, spon- 
taneous recovery of $\mathrm{Tl}$ from $10 \%$ to $25 \%, 75 \%$ and $90 \%$ of control took $11.3,24.3$, and $32.6 \mathrm{~min}$, respectively. At $75 \%$ recovery of $\mathrm{Tl}$, the TOF ratio was 0.48 . Administration of a mixture of $20 \mu \mathrm{g} \cdot \mathrm{kg}^{-1}$ neostigmine and $0.3 \mathrm{mg}$ glycopyrrolate at $75 \%$ recovery of $\mathrm{Tl}$ resulted in recovery of TOF to 0.98 in five minutes.

In the second anaesthetic; after a five-minute period of baseline stabilisation, $0.15 \mathrm{mg} \cdot \mathrm{kg}^{-1}$ mivacurium was administered. The first measurable effect (lag time) and the maximum neuromuscular block (onset time) developed in 70 and $210 \mathrm{sec}$, respectively. The maximum block attained was $99 \%$ inhibition of Tl. Thereafter, tracheal intubation was carried out. The first twitch (Tl) recovered to $10 \%$ of the control value $11.5 \mathrm{~min}$ after the administration of mivacurium. A supplementary dose of $0.1 \mathrm{mg} \cdot \mathrm{kg}^{-1}$ mivacurium was administered when $\mathrm{Tl}$ recovered to $10 \%$ of control value. The maximum block developed after the latter dose was $98 \%$ inhibition of $\mathrm{Tl}$ and occurred after $190 \mathrm{sec}$. Thereafter, recovery of $\mathrm{Tl}$ to $10 \%, 25 \%, 75 \%$ and 100 of control took $7.2,10,15$ and $27 \mathrm{~min}$, respectively. At $100 \%$ recovery of $\mathrm{Tl}$, the TOF ratio was 0.79 . No reversal was given after mivacurium. The patient made uneventful recovery after both anaesthetics.

\section{Discussion}

Sensitivity to vecuronium in patients with CMTD has been noted in two reports. ${ }^{2,9}$ Our patient with CMTD demonstrated a normal response to both atracurium and mivacurium. A similar observation was reported recently with vecuronium in a patient with CMTD. ${ }^{10}$ Although it has been suggested, in a retrospective review, that the use of neuromuscular blocking drugs is uneventful in patients with CMTD, ${ }^{8}$ it was not clear from this report what dose of muscle relaxants was used and how the neuromuscular block was monitored.

Naguib et al. ${ }^{11}$ noted, in normal patients, that the onset and duration of action of $0.5 \mathrm{mg} \cdot \mathrm{kg}^{-1}$ atracurium to $10 \%$ recovery of $\mathrm{Tl}$ during oxygen-nitrous oxideopioid anaesthesia were $119.5 \pm 25.8 \mathrm{sec}$ and $34.4 \pm$ 3.9 min (mean $\pm S D$ ), respectively. Corresponding times observed in this patient were similar to those in normal patients, being $240 \mathrm{sec}$ and $30 \mathrm{~min}$, respectively. Savarese $e t a l .^{12}$ reported that onset time and recovery index ( 25 to $75 \%$ recovery of $\mathrm{Tl}$ ) after $0.15 \mathrm{mg} \cdot \mathrm{kg}^{-1}$ mivacurium during oxygen-nitrous oxide-opioid anaesthesia were $3.3 \pm 0.3 \mathrm{~min}$ and $6.6 \pm 0.6 \mathrm{~min}$ (mean \pm $\mathrm{SE}$ ), respectively. Corresponding values in our patient were $190 \mathrm{sec}$ and $5 \mathrm{~min}$.

Baraka ${ }^{10}$ suggested that the normal response to nondepolarising neuromuscular blocking drugs in patients with generalised polyneuropathy, despite muscle weakness and atrophy, could be attributed to up-regulation of the acetylcholine receptors at the neuromuscular junction. ${ }^{13}$

Succinylcholine and malignant hyperthermia triggering agents have been used in CMTD patients without untoward effects. ${ }^{7,8}$ Although there is no clear evidence that CMTD predisposes patients to an increased risk of malignant hyperthermia, one patient with CMTD developed malignant hyperthermia after sevoflurane anaesthesia ${ }^{14}$ and another incident has raised the issue of malignant hyperthermia in CMTD. ${ }^{15}$ Therefore, one may wish to avoid drugs known to trigger malignant hyperthermia. Drugs that can trigger malignant hyperthermia (such as potent volatile anaesthetics and succinylcholine) were avoided in our patient. We used nitrous oxide, propofol atracurium and mivacurium; all of these drugs have been reported to be safe in susceptible patients. ${ }^{16}$

In patients with neuromuscular disorders, the antagonism of neuromuscular blockade and recognition of adequate return of neuromuscular activity is complicated by the presence of neuromuscular disease. There are reports of paradoxical worsening of neuromuscular blockade upon attempts to reverse blockade in patients with neuromuscular disorders such as dystrophia myotonia and progressive muscular dystrophy. ${ }^{17}$ Neostigmine was used successfully to antagonise the residual atracurium-induced neuromuscular blockade in the first anaesthetic in our patient without adverse sequelae.

In conclusion, we found no evidence of prolonged response to atracurium and mivacurium in our patient with CMTD.

\section{References}

1 Dyck PJ. Inherited neuronal degeneration and atrophy affecting peripheral motor, sensory and autonomic neurons. In: Dyck PJ, Lambert EH, Thomas PK (Eds.). Peripheral Neuropathy. Philadelphia: WB Saunders, 1975: 825-67.

2 Kotani N, Hirata K, Anzawa N, Takamura K, Sakai $T$, Matsuki $A$. Motor and sensory disability has a strong relationship to induction dose of thiopental in patients with the hypertropic variety of Charcot-MarieTooth syndrome. Anesth Analg 1996; 82: 182-6.

3 Brian JE Jr, Boyles GD, Quirk JG Jr, Clark RB. Anesthetic management for cesarean section of a patient with Charcot-Marie-Tooth disease. Anesthesiology 1987; 66: 410-2.

4 Eichacker PQ, Spiro A, Sherman M, Lazar E, Reichel J, Dodick $F$. Respiratory muscle dysfunction in hereditary motor sensory neuropathy, type I. Arch Intern Med 1988; 148: 1739-40. 
5 Nathanson $B N, \Upsilon u D-G, C h a n C K$. Respiratory muscle weakness in Charcot-Marie-Tooth disease. A field study. Arch Intern Med 1989; 149: 1389-91.

6 Chan CK, Mohsenin V, Loke J, Virgulto J, Sipski L, Ferranti $R$. Diaphragmatic dysfunction in siblings with hereditary motor and sensory neuropathy (CharcotMarie-Tooth disease). Chest 1987; 91: 567-70.

7 Greenberg RS, Parker SD. Anesthetic management for the child with Charcot-Marie-Tooth disease. Anesth Analg 1992; 74: 305-7.

8 Antognini JF. Anaesthesia for Charcot-Marie-Tooth disease: a review of 86 cases. Can J Anaesth 1992; 39: 398-400.

9 Fiacchino $F$, Grandi L, Ciano C, Sghirlanzoni A. Unrecognized Charcot-Marie-Tooth disease: diagnostic difficulties in the assessment of recovery from paralysis. Anesth Analg 1995; 81: 199-201.

10 Baraka AS. Vecuronium neuromuscular block in a patient with Charcot-Marie-Tooth syndrome. Anesth Analg 1997; 84: 927-8.

11 Naguib M, Abdulatif M, Gyasi HK, Absood GH. Priming with atracurium: improving intubating conditions with additional doses of thiopental. Anesth Analg 1986; 65: 1295-9.

12 Savarese J], Ali HH, Basta SJ, et al. The clinical neuromuscular pharmacology of mivacurium chloride (BW B1090U). A short-acting nondepolarizing ester neuromuscular blocking drug. Anesthesiology 1988; 68: 723-32.

13 Martyn JAJ, White DA, Gronert GA, Jaffe RS, Ward $J M$. Up-and-down regulation of skeletal muscle acetylcholine receptors. Effects on neuromuscular blockers. Anesthesiology 1992; 76: 822-43.

14 Ducart A, Adnet P, Renaud B, Riou B, Kriposic-Horber $R$. Malignant hyperthermia during sevoflurane administration. Anesth Analg 1995; 80: 609-11.

15 Roelofse JA, Shipton EA. Anaesthesia for abdominal hysterectomy in Charcot-Marie-Tooth disease. A case report. S Afr Med J 1985; 67: 605-6.

16 Khambatta HJ. Malignant hyperthermia and the anaesthesiologist. In: Felipe MAN, Gottmann S, Khambatta HJ (Eds.). Malignant Hyperthermia Current Concepts. Madrid: Normed Verlag, 1988: 11-8.

17 Buzello W, Krieg N, Schlickewei A. Hazards of neostigmine in patients with neuromuscular disorders. Report of two cases. Br J Anaesth 1982; 54: 529-34. 